\title{
A EFETIVIDADE DOS DIREITOS SOCIAIS À LUZ DO PARADIGMA
}

NEOCONSTITUCIONAL

\author{
THE EFFECTIVENESS OF SOCIAL RIGHTS THROUGH THE LENS OF A \\ NEOCONSTITUTIONAL PERSPECTIVE
}

António Luís Silva Baptista; ${ }^{1}$

Carolina de Freitas e Silva. ${ }^{2}$

Resumo: Trata-se de um breve estudo sobre a posição ocupada pelos direitos sociais, no quadro mais geral dos direitos fundamentais, à luz das experiências de "constitucionalização" das ordens jurídicas e do paradigma neoconstitucional. Esta teoria e prática vêm demandando uma postura mais proativa dos intérpretes da Constituição, particularmente dos juízes, em sede de controle da constitucionalidade, contra as ações e omissões inconstitucionais do poder político. O principal objetivo deste estudo é o de, a partir de uma análise de natureza jurídico-conceitual, apresentar e analisar criticamente as teses que foram propostas para, em contextos de crise econômica - como a que o Brasil presentemente vive -, desafiar a jusfundamentalidade dos direitos sociais e o seu caráter juridicamente vinculante. Conclui-se que todos os argumentos que buscam diferenciar os direitos sociais dos demais direitos fundamentais se mostram inválidos ou frágeis e que, por isso, uma Constituição só será suprema se todo o seu conteúdo for entendido como juridicamente vinculante.

Palavras-chave: Direitos sociais. Neoconstitucionalismo. Controle de constitucionalidade. Democracia. Crise.

Abstract: This is a brief study concerning the position of social rights within the larger framework of fundamental rights, conducted in light of the recent experiences of "constitutionalization" of legal orders. This is done through the lens of a neo-constitutional

\footnotetext{
${ }^{1}$ Graduou-se em Ciências Jurídicas pela Faculdade de Direito da Universidade Nova de Lisboa (2006), obteve o grau de Mestre em Política Comparada pelo Instituto de Ciências Sociais da Universidade de Lisboa (2009), doutorou-se em Teoria Política pela Universidade de Lisboa (2013). É Pós-Doutor pela Universidade de São Paulo (2014-2016) e investigador do Grupo de Teoria Política do Centro de Ética, Política e Sociedade da Universidade do Minho, Portugal. Tem experiência acadêmica na área da Ciência Política, com ênfase em Teoria Política.

${ }^{2}$ Em 2018 concluiu o Doutoramento em Direitos Sociais na Faculdade de Direito da Universidade Nova de Lisboa. Em 2016, concluiu o curso de Pós-Graduação em Práticas Forenses na Faculdade de Direito da Universidade Autónoma de Lisboa. Em 2011 concluiu o Mestrado em Direito do Trabalho na Faculdade de Direito da Universidade de Coimbra. Em 2008 concluiu a Graduação em Direito nas Faculdades Integradas Barros Melo, em Pernambuco, Brasil. Tem experiência em diversas áreas do Direito, no Brasil e em Portugal, com ênfase em Direito do Trabalho e Direito Processual do Trabalho. Exerce a advocacia em Portugal e é Investigadora Integrada Doutorada do Centro de Investigação e Desenvolvimento sobre Direito e Sociedade (CEDIS) da Faculdade de Direito da Universidade Nova de Lisboa.
}

Artigo recebido em 11/05/2016 e aprovado para publicação em 04/02/2019. 
paradigm, which demands a more "proactive" stance from constitutional interpreters. This is particularly true of judges when performing the judicial review of both actions and omissions by political officials. The main goal will be that of, by means of a conceptual analysis, both expounding and critically analyzing the claims that are pervasively proposed during economic crises - as the one Brazil is currently experiencing - so as to challenge the juridically binding character and fundamentality of social rights. All arguments that seek to establish a radical differentiation between social and other fundamental rights are shown to be either invalid or frail. Finally, it is asserted that a Constitution can only be the paramount law if all of its content is understood as juridically binding.

Keywords: Social rights. Neoconstitutionalism. Judicial review. Democracy. Crisis.

\section{INTRODUÇÃO}

Em tempos de crise e de grave austeridade no controle das contas públicas como os vividos até bem recentemente por muitas nações europeias, sobretudo as do sul da Europa, os discursos em torno das diferenças entre os direitos de liberdade e os direitos sociais, no sentido de desvalorizar a jusfundamentalidade destes últimos, reaparecem e tendem a se tornar preponderantes. Esses discursos servem para justificar certas opções políticas, normalmente relacionadas à redução do tamanho e do peso do Estado na sociedade e com o desinvestimento em políticas que concretizam ou realizam determinados princípios, valores constitucionais e direitos fundamentais no âmbito social.

O principal argumento lançado nessa tentativa de "refundação" do Estado Social Europeu é o de que a crise requer uma política exigente e permanente de contenção de despesas, uma reestruturação do Estado e uma "racionalidade" no gasto público. Implicitamente (e por vezes explicitamente) a este argumento está subjacente uma teoria social e filosófico-constitucional segundo a qual as constituições contemporâneas encerram, no seu seio, dois tipos de disposições jurídicas fundamentais, dois tipos de direitos, e, respectivamente, dois tipos de validades jurídicas. Se aos direitos tidos por "de liberdade" corresponderia uma máxima força, uma validade jurídica universal e transhistórica, intocável pelos circunstancialismos econômicos e sociais, aos outros direitos, os "sociais", estaria reservada uma espécie de validade e força constitucionais de segunda ordem, contingentes e variáveis, que seriam imediatamente suspensas em caso de superveniência de eventos como as crises.

Como pressupostos desta teoria implícita, e reforçando-a, surgem, entre outras, as seguintes teses de natureza pretensamente técnico-jurídica: a) a da indeterminabilidade dos 
direitos sociais, cabendo ao legislador e aos governos a sua realização de acordo com as suas agendas políticas; b) a de que os direitos sociais exigem uma atuação positiva do Estado, diferentemente dos outros direitos fundamentais que exigiriam apenas uma atitude de abstenção; c) a de que, tratando-se de direitos "positivos", e ao contrário daquilo que acontece com os chamados direitos de liberdade, os direitos sociais implicariam gastos e, por isso, a sua realização estaria dependente da observância do princípio da "reserva do financeiramente possível"; d) a de que aos juízes faltaria tanto a competência técnica quanto a legitimidade democrática, necessárias para avaliar e julgar, contra a opinião do legislador democraticamente respaldado e dos técnicos especializados, bem como contra as exigências do mercado, normas e decisões respeitantes aos direitos sociais e às "necessárias" reformas econômicas.

É claro que, em um cenário de relativa normalidade política, ou com poucas interferências especulativas do capital financeiro, qualquer medida de diminuição do patamar mínimo civilizacional a que chegaram os países seria bastante impopular e de difícil justificação. Contudo, a generalização do medo nos países periféricos europeus (medo de um Estado insolvente, medo das consequências negativas de saída da zona do Euro e medo de cenários catastróficos caso reajustes econômicos não fossem realizados) gerou um ambiente propício para o surgimento de uma espécie de "direito constitucional da exceção", ${ }^{3}$ defendido por alguns autores (RIBEIRO e COUTINHO, 2014), como se a crise produzisse o já referido fenômeno de "suspensão" da Constituição no tocante aos direitos sociais e como se as respectivas condicionantes financeiras devessem gozar sempre de preponderância em detrimento de um constitucionalismo forte e robusto. ${ }^{4}$

\footnotetext{
${ }^{3}$ Para uma análise sociológica e política sobre o uso estratégico das catástrofes ou dos "choques" para implementar e justificar reformas profundas e perniciosas que de outro modo seriam resistidas, ver a obra A doutrina do choque (KLEIN, 2008).

${ }^{4}$ Em Portugal, por exemplo, no período mais duro da austeridade, travou-se uma guerra contra os direitos sociais, na medida em que, objetivamente, os investimentos no setor público reduziram-se a mínimos históricos e foi operada uma verdadeira remodelação do Estado para o mínimo possível. Houve cortes significativos nos gastos em áreas estratégicas, tais como a saúde, a educação, "despesas sociais" (CES, 2013, p. 85 e ss), justificados pela necessidade de reajustamento da economia, pelo controle dos gastos públicos, e tendo efeitos bastante perversos a curtíssimo, a médio e longo prazo. Essas medidas foram impostas à sociedade portuguesa como única alternativa para o enfrentamento da crise e o seu cumprimento foi controlado (durante e após a execução do "memorando de entendimento") pelos credores do Estado português que, supostamente, "resgataram" o país da insolvência e que compunham a troika (Comissão Europeia, Banco Central Europeu e Fundo Monetário Internacional). Também fizeram parte das medidas do governo, levadas a cabo a partir de 2011, a diminuição dos gastos públicos com salários, remunerações, aposentadorias e prestações sociais. As empresas (da iniciativa privada) saíram também bastante privilegiadas com a diminuição com os gastos com o trabalho (ibid., p. 117 e ss). As medidas, além de perversas, foram retroativas, invalidando os princípios mais estruturantes da ordem jurídica portuguesa: o da proibição do retrocesso social, o da igualdade, o da confiança
} 
Se no Brasil, até agora, não tem havido espaço para uma produção de teoria constitucional militantemente mais "enfraquecida" como se observou em Portugal, por exemplo, por outro lado não é despiciendo ressaltar que, com a forte chegada da crise econômica que antes grassara na Europa e as alterações políticas posteriores ao afastamento da ex-presidente Dilma Rousseff, o clima intelectual mudou de forma decisiva. A falta de uma "teoria jurídica" forte e explícita não obstou à realização de reformas econômicas e sociais em detrimento dos direitos sociais mais básicos e, sustentadas em um argumentário similar ao aventado na Europa, não fez, até o momento, com que os tribunais, e o STF em particular, assumissem o papel de "freio" constitucional que lhe caberia. À semelhança também do que ocorreu em Portugal, por exemplo, foram conseguidas, em tempo recorde, alterações legislativas in pejus em matérias de direito do trabalho e previdênciário que há apenas alguns anos seriam impensáveis. Até instituições tão solidificadas no país, como a Justiça do Trabalho, estão sendo atualmente colocadas em causa com base em argumentos em tudo similares a alguns dos que foram avançados um pouco por toda a Europa

e o da segurança jurídica. Apenas a título ilustrativo da tábua rasa que foi feita de todas as conquistas sociais refira-se que houve: a perda do $13^{\circ}$ e $14^{\circ}$ salários dos funcionários públicos e dos aposentados; o aumento da jornada de trabalho dos trabalhadores no serviço público de 35 para 40 horas sem o correspondente acréscimo remuneratório; recorrentes "contribuições extraordinárias de solidariedade", e a aplicação retroativa de normas mais prejudiciais de cálculo dos valores da aposentadoria. As consequências nefastas de uma política de austeridade e de destruição dos direitos sociais atingiram de forma bastante violenta os desempregados ou subempregados: foram realizados cortes nos valores das prestações sociais para trabalhadores em situação de desemprego e restringido o acesso às mesmas; houve um aumento exponencial de empregos precários e, desde o início da aplicação das medidas de austeridade, houve um aumento do desemprego. Estima-se que, em dezembro de 2014, 81,8\% dos desempregados - considerado aqui o número oficial de desempregados, os desempregados ocupados, os inativos desencorajados e ativos migrantes - não tinham acesso a prestações e estavam em situação de desemprego há mais de dois anos. Quanto aos números do desemprego, ter-se-ão destruído, de 2011 até ao $2^{\circ}$ semestre de 2013, 463,6 mil postos de trabalho e criado apenas 37,9 mil postos de trabalho; de modo que, somando-se os índices reais de desocupação por falta de oportunidade de emprego e os índices de subemprego, estima-se que o desemprego tenha chegado ao alarmante índice de $29,1 \%$ em dezembro de 2014. Dos empregos criados, entre 60 a $66 \%$ dos postos de trabalho são altamente precários, sem qualquer garantia de continuidade, e apoiados com fundos públicos. A situação de subemprego que abrangia cerca de 213,9 mil pessoas no $1^{\circ}$ trimestre de 2011 chegou a atingir, no $4^{\circ}$ trimestre de 2014 , a marca dos 251,7 mil (CES, 2015). Com a entrada em funções de um novo executivo para a legislatura 2015-2019, condicionado por um acordo com forças políticas mais à esquerda, e gozando da importante mudança de orientação e de políticas dentro do Banco Central Europeu, a situação foi atenuada, revertendo-se (parcialmente) a austeridade anteriormente praticada (reposição de $13^{\circ}$ e $14^{\circ}$, eliminação de uma sobretaxa, retorno das 35 horas semanais, aumento do salário mínimo, entre outras medidas), e gerando-se um ciclo mais positivo na economia, com a contenção do aumento da dívida, a subida substancial do emprego, da demanda interna e do PIB. Ainda assim, a recuperação econômica não conseguiu superar e sanar muitos dos problemas criados pela devastação da crise e das políticas antissociais. Em virtude das alterações provocadas na realidade laboral portuguesa pelas medidas do período da crise e ainda pouco contrariadas, a estrutura do emprego em Portugal modificou-se em um sentido negativo, verificando-se um elevadíssimo índice de precariedade e de baixa qualidade no emprego, enquanto os salários médios tendem a baixar ou a estagnar (id., 2018a e 2018b). Entretanto, neste novo clima, foi de algum modo esquecido (temporariamente) muito do reportório argumentativo contra os direitos fundamentais sociais e a sua proteção constitucional a que aqui se faz referência e se critica. 


\section{RFD}

Mediterrânica. Por fim, a chamada "PEC do fim do mundo" (n 95/2016) é o exemplo mais acabado e extremo de até onde pode ser levada a lógica interna subjacente às teses que aqui se buscam analisar e criticar.

Entre nós, é certo, existe uma jurisdição constitucional que procura explorar, com erros e acertos, avanços e recuos, todo o conteúdo principiológico e valorativo inscrito na Constituição, ainda que o seu "ativismo judicial" seja alvo de várias críticas - por vezes justificadas. Contudo, e ainda que a "carta cidadã" tenha sido considerada, até aqui, um importante instrumento para a emancipação social, a "imunidade" aparente do Brasil até 2016 às teses e aos pressupostos do "discurso austeritário" aqui criticamente explorados revelou-se afinal puramente ilusória.

O pressuposto que permeia todo o debate aqui encetado é o de que, em um contexto de constitucionalização das ordens jurídicas, ou de neoconstitucionalismo, todo o conteúdo da carta constitucional é composto por verdadeiras normas jurídicas, materialmente vinculantes e conformadoras do poder político (PIOVESAN, 2010, p. 56). E será assim, a menos que o texto das cartas fundamentais seja alterado (formal e materialmente) por maiorias qualificadas ou por verdadeiras revoluções. Ressalte-se que é justamente em circunstâncias de crise que as pessoas estão mais fragilizadas e, por isso mesmo, necessitam de uma maior assistência do Estado. Então, é nessas circunstâncias que a Constituiç̧ão passa a ser um poderoso instrumento contra o desmantelamento das principais conquistas da luta pelo reconhecimento, expansão e concretização de direitos.

O objetivo do presente artigo é o de operar uma desconstrução analítica e refutação dos argumentos e teses que, de uma forma transversal, podem aparecer nos países de constitucionalismo "forte" com o objetivo de enfraquecer o "poder regulador" da Constituição. Metodologicamente, trata-se de uma análise de natureza conceitual, ancorada em uma perspectiva jurídico-filosófica dos direitos fundamentais e do direito constitucional, que se buscará explanar sucintamente, e que se julga poder enquadrar dentro da categoria algo ampla do chamado movimento "neoconstitucional".

É, portanto, um exercício fundamentalmente argumentativo, abstrato e jurídicofilosófico - naturalmente, e não obstante ocasionais referências a jurisprudência e os dispositivos constitucionais concretos, retirados da prática portuguesa e brasileira - a razão pela qual não se buscará aqui estudar detalhadamente as especificidades do sistema jurídico brasileiro nem as de qualquer outra ordem jurídica em particular. O que se procurará 
averiguar, portanto, e mais abstratamente, é se, e em que medida, será legítimo sustentar, como o fazem algumas teses, a existência de diferenças estruturais entre os direitos ditos "de liberdade" e os direitos sociais e, por outro, questionar se é ou não cabível um controle judicial relativamente ao cumprimento destes últimos ou se essa fiscalização deverá ser diferenciada daquela que é dispensada aos demais direitos.

Antes de entrar no cerne da discussão, na quarta seção, convém, porém, preliminarmente e para melhor compreensão do contexto e marco teórico em que este artigo se move, expor sucintamente aquilo a que se designou por "movimento neoconstitucional" (na seção 2) e as consequências teóricas gerais do mesmo para a teoria constitucional, bem como oferecer algumas considerações iniciais sobre a temática dos direitos sociais (seção 3).

\section{O NEOCONSTITUCIONALISMO}

À sombra da designação "neoconstitucionalismo", como faz questão de enfatizar Carlos Bernal Pulido, pretendeu-se abranger tanto o constitucionalismo europeu (a prática constitucional) do pós-guerra, incluindo aí experiências diversas, como as do ativismo judicial da Alemanha e as sentenças aditivas na Itália, como, simultaneamente, as ideias expostas por autores muito diversos, em alguns casos com posições até incompatíveis entre si, acerca do bom modo de entender e interpretar a Constituição e as suas normas (PULIDO, 2007, p. 301). Há quem fale, alternativamente, em "constitucionalização" das ordens jurídicas para, grosso modo, identificar o mesmo fenômeno (GUASTINI , 2003, p. 39). ${ }^{5}$

Esse processo de constitucionalização das modernas ordens jurídicas resultou no reposicionamento das respectivas constituições de Estado para o centro de cada ordenamento jurídico, de modo a que a Carta Fundamental se tornasse o padrão de medida de todas as demais normas, contribuindo para a construção da ideia de um direito "maleável” ou "dúctil”, de que Zagrebelsky fala. A maleabilidade do direito se oporia frontalmente àquela antiga visão positivista de uma ciência jurídica quase mecânica, de aplicação irrefletida de regras,

\footnotetext{
${ }^{5}$ Segundo Riccardo Guastini “(...) ‘por constitucionalización de ordenamiento jurídico’ propongo entender un proceso de transformación de un ordenamiento al término del cual el ordenamiento en cuestión resulta totalmente impregnado por las normas constitucionales. Un ordenamento jurídico constitucionalizado se caracteriza por una constitución extremadamente invasora, entrometida (pervasiva, invadente), capaz de condicionar tanto la legislación como la jurisprudencia y el estilo doctrinal, la acción de los actores políticos, así como las relaciones sociales". Este é, porém, um conceito gradativo: nenhuma sociedade é completamente constitucionalizada nem muito menos completamente "desconstitucionalizada"(GUASTINI, 2003, p. 39).
} 
cedendo lugar a um direito dos princípios, que se rege pelo pluralismo valorativo e pela ponderação (a "concordância prática" entre esses princípios), e não pela preponderância absoluta de uns em detrimento de outros (ZAGREBELSKY, 2009, p. 109 e ss.).

De fato, esse movimento de constitucionalização das ordens jurídicas e a defesa intransigente da Constituição, dos direitos e princípios que ela encerra, são identificados e justificados por uma teoria chamada de neoconstitucionalista que, por seu turno, aglomera em si variadas concepções para explicar e defender esse novo papel paradigmático da Constituição. Não obstante a polissemia do termo, e levando em conta as cautelas a que esta constatação nos convida, talvez não seja totalmente incorreto definir o neoconstitucionalismo como uma corrente de pensamento ou um tipo de sensibilidade jurídico-ideológica que foi simultaneamente influenciada por uma jurisprudência constitucional de cunho mais “intervencionista" ou proativa na defesa da Constituição contra o legislador recalcitrante, e por uma doutrina constitucionalista que, também ela influenciada pela jurisprudência anterior, teorizou e justificou esse movimento.

Mas, afinal, em que consiste esta nova forma de pensar a Constituição e a jurisdição constitucional? Segundo Luís Prieto Sanchís, esta nova "cultura jurídica” está em oposição às concepções positivistas que dominaram a Teoria do Estado e do Estado de Direito no século XIX e caracteriza-se por dois principais traços (SANCHÍS, 2007). ${ }^{6}$

Em primeiro lugar, no seio do entendimento neoconstitucionalista, pensa-se nas cartas fundamentais, não como meros documentos formais, mas como instrumentos que contêm verdadeiros conteúdos substantivos ou materiais que se impõem face ao Estado - aos governos e aos legisladores em particular. Entre estes conteúdos, incluem-se princípios e valores ou diretrizes que dizem ao poder, não apenas como ele deve se organizar e quais os procedimentos que deve adotar quando pretenda tomar decisões e emitir leis, mas, mais

\footnotetext{
${ }^{6}$ Cabe assinalar que há muito de exagero na proclamada "morte" ou insustentabilidade do positivismo jurídico. Algo causado, provavelmente, por uma certa ambiguidade ou incorreta identificação do que constitui o "positivismo". H. Hart buscava simplesmente afirmar a distinção entre o direito que existe ("law as it is") e a moral ("law as it ought to be"), insistindo tão só que mesmo uma norma jurídica moralmente injusta - como as normas do ordenamento jurídico da alemanha nazista - não deixavam de ser direito positivo, a partir do ponto de vista do que era a prática juridica dos agentes (juízes em particular). Além do mais, H. Hart, em resposta a Dworkin, admitiu expressamente o papel relevante que os princípios podem desempenhar na definição do que constitui o direito positivo. Admitiu também que as normas (particularmente os princípios) podem ter uma zona de penumbra semântica alargada - falava mesmo da "textura aberta" das normas - que permitiam que nos "casos difíceis" os valores morais positivados pela ordem jurídica, nomeadamente pelas constituições, interviessem fortemente no julgamento dos juízes e que gerassem, por isso, uma indeterminação relativa do que constitui o direito positivo (HART, 2007, p.16-17 e 314).
} 
significativamente, "qué es lo que puede e incluso, a veces, qué es lo que debe decidir" (SANCHÍS, 2007, p. 213-214).

Em segundo lugar, a Constituição e estas normas materiais estão "garantidas". Isto quer dizer, na prática, que contra um parlamento eventualmente obstinado a não seguir as instruções constitucionais, opõem-se os juízes que estão devidamente legitimados pelo texto constitucional para agirem como defensores da efetividade da Constituição e das suas normas substantivas, em particular dos direitos fundamentais. Significa dizer que, ao contrário do que até então sucedia na Europa, e em um movimento de aproximação à judicial review americana, que já levava mais de um século de avanço nesta matéria, para lá das questões orgânicas e formais, a Constituição passou a "valer" como juridicamente vinculante (e dispõe de mecanismos próprios para assegurar essa vinculação), mesmo quando estabelece direitos sem grande densificação ou quando proclama princípios mais abstratos (ibid., p. 216). ${ }^{7}$

Os princípios, nomeadamente o da igualdade e o da dignidade da pessoa humana, afinal, não são promessas vazias a serem preenchidas pelo legislador democraticamente eleito a seu bel-prazer. Mais ainda, não apenas as regras, mas também os princípios constitucionais dizem e impõem muito mais do que até então se pensara. A Constituição, afinal, estende-se e coloniza tendencialmente toda a ordem jurídica: os seus princípios e direitos irradiam para todas as áreas e afetam todos os produtos normativos do Estado e, eventualmente, influem até nas relações privadas, em um movimento que claramente contrasta e se opõe ao pensamento tradicional. ${ }^{8}$ Subjacente a esta ideia, surgirá a noção de que, para além do sentido puramente literal e isolado das normas, em uma Constituição é possível, desejável e, em última análise, necessário, encontrar toda a riqueza de conteúdos jurídicos que emanam da leitura conjugada e sistemática de princípios, explícitos e implícitos. A Constituição faz uso de uma "regulação principialista" e convida não só os legisladores, os governos, mas

\footnotetext{
7 "Ni siquiera los derechos que reclaman una interpositio legislatoris son, mientras ésta no se produce, simples recomendaciones carentes de fuerza jurídica; tienen siempre un contenido normativo que puede ser hecho valer desde la Constituición misma. Y que puede ser hecho valer, cuando proceda, ante cualquier jurisdición: 'La constitucionalización no es simplesmente (...) la mera enunciación formal de un princípio hasta ahora no explicitado, sino la plena positivización de un derecho, a partir de la cual cualquier ciudadano podrá recabar su tutela ante los Tribunales ordinarios (STC 56/1982)"' (PRIETO SANCHÍS, 2007, p. 216).

8 "Los derechos fundamentales (...) exhiben una extraordinaria fuerza expansiva que inunda, impregna, o irradia sobre el conjunto del sistema; ya no disciplinan únicamente determinadas esferas públicas de relación entre el indivíduo y el poder, sino que se hacen operativos en todo tipo de relaciones jurídicas de manera que bien puede decirse que no hay un problema medianamente serio que no encuentre respuesta o, cuando menos, orientación de sentido en la constituición y en sus derechos" (ibid., p. 213-214).
} 


\section{RFD}

também, e principalmente, os juízes a leituras mais amplas e criativas (PULIDO, 2007, p. 290) das suas disposições materiais.

A força dos princípios constitucionais tornou-se uma realidade incontornável e para isto terá contribuído em muito a distinção forjada por Ronald Dworkin, na sua obra, "Taking Rights Seriously", entre princípios e regras, no âmbito do seu ataque ao positivismo de Hart (2007). Os princípios distinguem-se das regras, em Dworkin, da seguinte forma: as regras aplicam-se em termos taxativos, de "tudo-ou-nada" (ou são válidas e as consequências jurídicas devem ser aceitas, ou não são válidas e, então, não contribuem para a decisão), ao passo que os princípios, mais do que dar indicações muito concretas e taxativas para uma decisão, oferecem razões que apontam, ou orientam, no sentido de se decidir um caso em uma determinada direção, embora não exijam taxativamente essa solução. Além disso, quando regras estão em conflito, uma delas, por ser inválida, terá de ser afastada em prol da outra; enquanto que, quando dois princípios que se interceptam apontam em sentidos diferentes, o aplicador do direito deve levar em conta e ponderar qual o valor relativo de cada um dos deles em uma perspectiva mais global (DWORKIN, 1997, p. 24-28). Os princípios e nesta matéria (de interpretação) os direitos fundamentais devem ser entendidos também como tais - "pesam-se" e, quando em conflito uns com os outros, comparam-se os "pesos relativos" de cada um à luz do caso concreto que os coloca em confronto.

Apesar do visível progresso do neoconstitucionalismo na maioria das democracias constitucionais, nota-se, por vezes, que, em matéria de direitos sociais, persiste uma resistência em tratar as disposições que os consagram exatamente da mesma forma como se tratam aquelas que consagram os chamados "direitos de liberdade", ou seja, os direitos civis e políticos, direitos de defesa ou simplesmente direitos de primeira geração (BOBBIO, 1992, p. 32), como se as duas categorias de direitos não fossem iguais em dignidade e vinculatividade jurídica; como se, nesse âmbito, a Constituição já não devesse ser interpretada como realmente "material". Em tempos de crise e de grande condicionamento financeiro dos Estados, o tema do cumprimento da Constituição na parte dos direitos fundamentais sociais volta à tona. As páginas que se seguem pretendem justamente analisar se efetivamente os direitos sociais merecem esse tratamento diferenciado ou não e, se sim, o porquê.

\section{DIREITOS SOCIAIS: CONSIDERAÇÕES GERAIS}


Pode-se dizer, por um lado, que os direitos sociais são direitos fundamentais na medida em que o próprio texto constitucional assim os define. A enunciação mais desenvolvida de direitos, que abrange os chamados direitos sociais e econômicos, ocorre normalmente em constituições mais longas ou analíticas, tais como a portuguesa e a brasileira. Estas traçam não apenas normas sobre a organização e os limites do poder, mas também consagram um amplo rol de direitos fundamentais que extrapola os clássicos direitos de liberdade ou de defesa, reconhecendo, portanto, textualmente, direitos que refletem o grau de desenvolvimento a que chegaram as sociedades modernas.

Neste sentido, o art. $6^{\circ}$ da Constituição brasileira enuncia em termos não taxativos os direitos fundamentais sociais consagrados "são direitos sociais a educação, a saúde, a alimentação, o trabalho, a moradia, o lazer, a segurança, a previdência social, a proteção à maternidade e à infância, a assistência aos desamparados, na forma desta Constituição".

Trata-se de um rol não taxativo, tendo em vista o disposto no $\S 2^{\circ}$ do art. $5^{\circ}$, segundo o qual "os direitos e garantias expressos nesta Constituição não excluem outros decorrentes do regime e dos princípios por ela adotados, ou dos tratados internacionais em que a República Federativa do Brasil seja parte".

Todos esses direitos são considerados fundamentais, porque estão enunciados no capítulo II que, por sua vez, está abrangido pelo título II da Constituição, denominado "Dos direitos e garantias fundamentais". Por serem direitos fundamentais, possuem aplicação imediata, por força do $\S 1^{\circ}$ do art. $5^{\circ}$ da Constituição, o qual dispõe que "as normas definidoras dos direitos e garantias fundamentais têm aplicação imediata".

Nota-se que esta forma abstrata de enunciar direitos deixa antever uma "sombra" de indeterminabilidade na apresentação das normas. Este é um recurso comum utilizado em várias constituições, sobretudo em relação a direitos que apresentam uma dimensão prestacional muito marcada. No caso da Constituição brasileira, pode-se dizer que os direitos sociais não padecem de uma indeterminabilidade generalizada, pois existem outros dispositivos constitucionais que vinculam mais pontual e concretamente as atividades do poder político no cumprimento desses direitos, ao reconhecer, por exemplo, a irredutibilidade salarial (art. $7^{\circ}$, V) e dos benefícios previdenciários (art. 194, IV); a universalidade da cobertura e do atendimento relativamente aos serviços de saúde, previdência e assistência 


\section{RFD}

social (art. 194, I); a educação básica, obrigatória e gratuita e a progressiva universalização do ensino médio gratuito (art. 208).

Entretanto, isso não significa, diga-se já, que as disposições mais genéricas, presentes no art. $6^{\circ}$ e em outros locais, e que não tenham sido objeto de densificação constitucional pelo legislador originário, não vinculam os poderes legislativo e executivo. Não apenas vinculam, dado que são normas jurídicas, como indicam o caminho para o qual a sociedade deve avançar (PIOVESAN, 2010, p. 56), independentemente da agenda política a ser adotada e legitimada pelo regime democrático. Não será de todo insignificante ressaltar que o Estado Democrático de Direito brasileiro tem como fundamentos, por exemplo, a cidadania, a dignidade da pessoa humana e os valores sociais do trabalho e da livre iniciativa (art. $1^{\circ}$, incisos II, III e IV) e deve garantir a construção de uma sociedade livre, justa e solidária; a erradicação da pobreza, da marginalização e a redução das desigualdades sociais e regionais; e a promoção do bem de todos sem preconceitos nem discriminações (art. $3^{\circ}$, incisos I, III e IV).

Por outro lado, esse caráter jusfundamental dos direitos sociais pode não decorrer apenas e simplesmente da sua enunciação expressa - ainda que em termos indeterminados , mas também ser produto da concretização pelo Executivo ou pelo Legislativo de regras principiológicas implícitas e explícitas constantes do texto constitucional. Os direitos fundamentais sociais, nesse sentido, surgiriam do exercício de concretização de dispositivos constitucionais mais abstratos, por iniciativa do governo ou do legislador ordinário, procedendo-se a uma normatização com um elevado grau de precisão e certeza, por razões, inclusive, de igualdade e de segurança jurídica (NOVAIS, 2010, p. 152). Uma vez concretizados esses princípios ou direitos fundamentais, não seria permitido um retrocesso civilizacional, um "retirar" dos direitos e garantias que já estão incorporados no patrimônio jurídico de cada indivíduo (PIOVESAN, op. cit., loc. cit.).

Com efeito, ainda que um direito não apresente forte densificação no texto constitucional, e desde que tenha havido concretização posterior do seu conteúdo por via infraconstitucional, este grau de realização já alcançado não poderá ser simplesmente eliminado, voltando-se à estaca zero de realização, por força de um princípio constitucional implícito que é o da "proibição do retrocesso social". Por maioria de razão, esta conclusão também será válida para os casos em que o próprio texto constitucional não se mostrar 
completamente vago, revelando já uma relativa concretização sobre o modo como o direito em causa deverá ser institucionalizado.

As alterações legislativas, particularmente as in pejus, não estão constitucionalmente bloqueadas, na medida em que podem existir outros bens jurídicos e princípios constitucionalmente relevantes que, legitimamente, na visão dos representantes da maioria, sejam preponderantes, sobrepondo-se a determinadas políticas concretizadoras de um direito social. Ainda assim, a liberdade de conformação do legislador ordinário está relativamente limitada: caso opte pela alteração legislativa, deverá proceder à substituição das medidas existentes por outras de efeito equivalente, pelo menos de modo a preservar o núcleo essencial do direito já realizado.

O Tribunal Constitucional Português, ao analisar o pedido de apreciação preventiva da constitucionalidade, formulado pelo Presidente da República, a respeito de uma alteração legislativa que restringia o acesso a prestações sociais (denominadas "rendimento social de inserção"), delimitou o alcance e limites do princípio da proibição do retrocesso social: “é necessário harmonizar a estabilidade da concretização legislativa já alcançada no domínio dos direitos sociais com a liberdade de conformação do legislador". Portanto, "a margem de liberdade do legislador para retroceder no grau de protecção já atingido é necessariamente mínima, já que só o poderá fazer na estrita medida em que a alteração legislativa pretendida não venha a consequenciar uma inconstitucionalidade por omissão (...)". Para o Tribunal, a aplicação do princípio da proibição do retrocesso social deve ser considerada no sentido de proibir que haja uma "aniquilação" do núcleo essencial ou que a redução do conteúdo do direito social viole o princípio da igualdade, da proteção da confiança ou, ainda, que atinja "o conteúdo de um direito social cujos contornos se hajam iniludivelmente enraizados ou sedimentados no seio da sociedade".

A exata extensão deste núcleo essencial de um direito fundamental não só variará em função do direito concreto em causa e da cultura local da comunidade jurídica, mas será sempre motivo de razoável dúvida. Em todo o caso, como nota Ingo Wolfgang Sarlet, dada a autonomia parcial, do ponto de vista dogmático, do princípio da proibição do retrocesso social em relação ao princípio da dignidade da pessoa humana e ao conceito de mínimo existencial, é razoável entender que alterações legislativas serão inconstitucionais, por violação da proibição do retrocesso social, mesmo quando as restrições que elas preveem não sejam diretamente ofensivas da dignidade da pessoa humana, na medida em que atinjam o 
núcleo essencial do direito social. Com efeito, uma parte - apenas - do núcleo essencial dos direitos fundamentais, variável de caso para caso, mantém uma relação intrínseca com a dignidade da pessoa humana e com o mínimo existencial e, por isso, estes dois critérios, apesar de representarem patamares mínimos do controle da constitucionalidade, não esgotam o sentido e o poder normativo autônomo do princípio da proibição do retrocesso (SARLET, 2010, p. 101 e ss.).

O recurso a este princípio da proibição do retrocesso social tem sido utilizado por teóricos constitucionalistas para defender a irredutibilidade de um certo patamar civilizacional, um núcleo mínimo dos direitos sociais a ser garantido pelo Estado e exigível pelos cidadãos. Por outro lado, muito se tem discutido, no âmbito da teoria e da prática da jurisdição constitucional, sobre a liberdade de conformação a ser reconhecida ao legislador para implementar leis que pretextem contornar os efeitos da crise econômica por meio de políticas de austeridade. Diante do debate entre estas duas correntes, que fluem em sentidos contraditórios, será útil e pertinente refletir sobre o espaço ocupado pelos direitos sociais nas atuais democracias constitucionais que, como se disse, não estão imunes a crises, nem muito menos às ofensivas doutrinárias que as acompanham. Existirá, afinal de contas, alguma diferença, em termos de jusfundamentalidade, entre os chamados direitos de "defesa" ou de "liberdade" e os direitos sociais, a ponto de justificar um tratamento ou uma postura interpretativa diferenciada? A próxima seção pretende dar um contributo justamente para este debate.

\section{O QUE DIFERENCIA OS DIREITOS SOCIAIS DOS DEMAIS? OS VÁRIOS ARGUMENTOS}

\subsection{OS DIREITOS SOCIAIS SÃO INDETERMINADOS?}

Um dos argumentos lançados para defender a existência de diferenças entre os diversos direitos fundamentais é o de que os direitos sociais padeceriam de uma imanente indeterminabilidade do seu conteúdo, o qual, por sua vez, só poderia ser revelado pelo exercício da interpretação (QUEIROZ, 2006, p. 36), a ser realizada pelo poder político, segundo as regras do jogo democrático. Nesse sentido, a consagração de direitos em termos bastante vagos ou abstratos, sujeitos a uma posterior densificação à luz do desenvolvimento de políticas concretizadoras, seria uma característica intrínseca e exclusiva dos direitos 


\section{RFD}

sociais, uma vez que os direitos de liberdade, isto é, os direitos civis e políticos, estariam já suficientemente conformados, de tal forma que o seu cumprimento poderia ser, inclusive, exigível judicialmente com base apenas nas disposições constitucionais.

Sucede que o problema da indeterminabilidade dos direitos fundamentais não é privativo dos direitos sociais: observa-se, por exemplo, o direito de acesso à justiça, ou seja, o direito de proteger os nossos próprios direitos em juízo. Não se trata de um direito social, mas de um direito instrumental à efetivação de qualquer direito fundamental, e depende, em muito, da interpretação que o Legislativo possa dar sobre o modelo ideal de sistema de justiça que garantiria o seu acesso mais facilitado (QUEIROZ, 2006, p. 36). A criação e manutenção de um sistema robusto, coerente, funcional e, sobretudo, que seja capaz de dar efetividade ao referido direito fundamental, dependerá, necessariamente, da sua interpretação pelo poder político.

Este direito, como os demais, não obstante os termos vagos em que se encontra formulado, deve ser interpretado à luz de outros princípios e valores constitucionais que iluminam parcialmente o caminho a ser trilhado pelo poder político: no âmbito de um Estado de Direito, nenhum legislador ou intérprete autorizado poderá desrespeitar o princípio da igualdade, nem esquivar-se a enfrentar eventuais entraves de natureza social e econômica que obstaculizem o acesso ao sistema judicial por parte dos desfavorecidos. Impõe-se a leitura deste (e qualquer outro) direito nos termos de uma interpretação sistemática da Constituição, considerando todos os princípios e valores relevantes e interrelacionados que se constituem sob a forma de uma rede semântica que afasta parcialmente as penumbras que subsistem em normas indeterminadas. Assim, em relação ao sistema judicial e ao direito de acesso à justiça, há de se considerar princípios como os que enformam os processos civil e penal, o princípio do juiz natural, o direito à "razoável duração do processo", à "celeridade de sua tramitação" etc.

Por essa mesma razão, a fiscalização da constitucionalidade dessas normas “indeterminadas" (por ação ou por omissão, parcial ou total) não surge como irrazoável, nem muito menos impossível. Com base na metodologia acima referida, caberá ao juiz perquirir se uma determinada lei ou ato normativo, do legislativo ou do executivo, realiza ou não o direito fundamental vindicado.

Considerações em tudo similares podem ser tecidas quanto a um exercício de clarificação de sentido do direito à propriedade, tal como disposto no art. $5^{\circ}$, XXII. Ainda que 


\section{RFD}

vagamente definido, o direito de propriedade está "reforçado" pelo princípio da livre iniciativa (art. $1^{\circ}$, inciso IV) e limitado pelos princípios do valor social do trabalho (art. $1^{\circ}$, inciso IV) e da função social da propriedade (art. $5^{\circ}$, inciso XXIII; art. 182, §2ª art. 186); está ainda balizado pelos princípios enformadores da ordem econômica (art. 170) e constrangido pela necessidade dos impostos sobre a propriedade etc. Nota-se ainda que o direito de propriedade, além de ser indeterminado, também entra facilmente em conflito com outros direitos fundamentais (como os dos trabalhadores), mas que nem por isso lhe é atribuído um status secundário. Como é próprio da natureza dos direitos fundamentais, será sempre necessário realizar um exercício de ponderação caso ocorram tais conflitos.

$\mathrm{O}$ que sucede com os direitos sociais é essencialmente $\mathrm{O}$ mesmo. $\mathrm{O}$ direito à alimentação, por exemplo, tem o seu conteúdo parcialmente iluminado também pelo conjunto do texto constitucional, de tal modo que a privação alimentar sofrida por alguns cidadãos sempre seria uma afronta à Constituição, atendendo, nomeadamente ao objetivo do Estado Democrático de Direito de "erradicar a pobreza e a marginalização e reduzir as desigualdades sociais e regionais" (art. $3^{\circ}$, inciso III), que se alicerça, por sua vez, no princípio da dignidade da pessoa humana (art. $1^{\circ}$, inciso III), algo que é reforçado pelo fato de a seguridade social, que tem como um dos seus pilares a assistência social, estar obrigada a garantir universalidade de cobertura e de atendimento (art. 194, parágrafo único, inciso I). Embora a sua relativa indeterminabilidade, em tudo similar àquela que verificamos existir no caso do acesso à justiça e do direito de propriedade, existem instrumentos processuais e instituições independentes que podem propor a respectiva ação judicial a fim de fiscalizar o cumprimento deste direito previsto na Constituição.

Embora o argumento não seja novo, no contexto da crise, recebeu novo impulso, havendo entre os juristas portugueses quem tenha avançado na teoria de que determinados direitos, os de natureza prestacional, seriam direitos sem capacidade de "resistência à lei", por supostamente não serem “determinados e determináveis a nível constitucional”, isto é, pelo fato de o seu conteúdo mais concreto ser apenas concretizado por leis ordinárias, e por estarem, ainda, dependentes da "reserva do possível". ${ }^{9}$ Se é o legislador ordinário quem produz e concretiza estes direitos prestacionais, seria também ele quem, nesta lógica, poderia

\footnotetext{
${ }^{9}$ Esta posição é sustentada por Maria Lúcia Amaral, professora e juíza Conselheira do Tribunal Constitucional Português, tanto no seu voto de vencida aposto ao Acórdão 353/2012 em que se discutia a inconstitucionalidade da suspensão do direito ao $13^{\circ}$ e $14^{\circ}$ salários enquanto violação do direito fundamental dos trabalhadores à retribuição (e à não diminuição da mesma) como na sua obra (AMARAL, s/d, p. 12 ss.)
} 
livremente modificá-los ou até, no limite, extingui-los. Novamente a resposta a esta variante do mesmo argumento não pode deixar de ser aquela dada por Jorge Reis Novais (2014, p. 148): "Os direitos sociais ou são uma coisa ou são outra: se estão na disponibilidade do legislador não são direitos fundamentais; se são direitos fundamentais o legislador fica vinculado a eles."

A Constituição portuguesa, é certo, não determina no seu texto, por exemplo, que os assalariados (do setor público ou privado) devem ter necessariamente um $13^{\circ}$ e um $14^{\circ}$ mês, nem qual deveria ser o quantitativo a receber pelos trabalhadores. Mas, como se explicou na seção 3, e em virtude do princípio de não retrocesso social, uma vez concretizados determinados direitos constitucionais, tal como o direito à retribuição contido no art. $59, \mathrm{n}^{\circ}$ 1 da Constituição Portuguesa, por meio das leis ordinárias que consagraram os direitos ao $13^{\circ}$ e $14^{\circ}$ mês, esta concretização adicional de algum modo se incorpora e passa a fazer parte do núcleo essencial do mesmo direito, não podendo ser pura e simplesmente aniquilada pelo legislador ordinário subsequente e sem fundamento em outros princípios constitucionalmente ponderosos, sob pena de se incorrer em uma violação do direito fundamental em causa. Como muito bem relembra o professor Jorge Reis Novais (2014, p. 150-153), também a liberdade de imprensa não inclui alguns direitos mais precisos, alguns elementos concretizadores deste direito, que foram introduzidos e regulados por leis ordinárias, como os constantes do estatuto dos jornalistas. No entanto, ninguém ousaria sustentar que esses direitos adicionais, concretizadores da liberdade de imprensa, por não serem "determinados a nível constitucional", não apresentariam "resistência à lei" e estivessem sujeitos a um controle constitucional de "segunda", não intensivo, ou como por vezes é designado, um mero "controle de evidência”, um controle leve que apenas leva à invalidação de normas legais quando estas são manifestamente irracionais ou arbitrárias (NOVAIS, op. cit., p. 134-135).

À luz destas considerações será possível concluir que, na realidade, dificilmente um direito fundamental será tão indeterminado a ponto de não se poder exigir, dos poderes políticos, a sua concretização, nem se poder realizar o controle da constitucionalidade de atos normativos e administrativos.

\subsection{OS DIREITOS SOCIAIS DEMANDAM UMA ATITUDE POSITIVA DO ESTADO?}


Os direitos sociais impõem ao Estado os deveres de respeito e de proteção a certas prerrogativas, de modo a permitir que todos os indivíduos tenham acesso a bens jusfundamentais sociais indisponíveis, ao bem-estar e a uma vida digna, protegendo o acesso a esses bens contra agressões e intervenções restritivas - algo que implica, naturalmente, e por maioria de razão, a abstenção do próprio Estado de promover, ele próprio, esses mesmos ataques. Os direitos sociais também impõem ao Estado o dever de realizar prestações fáticas com o fito de promover o acesso aos bens indisponíveis daqueles que não possuem recursos próprios para tanto. É justamente porque a maior parte das pessoas não dispõe de recursos próprios para garantir o acesso aos bens jurídicos protegidos que o dever estatal de prestações sociais sobressai e acaba por ser a principal e mais marcante característica dos direitos sociais. Isto não quer dizer, por um lado, que os direitos sociais se confundam necessariamente e exclusivamente com uma atuação positiva do Estado no sentido de realizar prestações sociais; também não quer dizer que se encontrem em um plano distinto relativamente aos direitos de liberdade, os quais, supostamente, apresentariam apenas uma natureza negativa, ou seja, apenas exigiriam uma atitude abstencionista do Estado (NOVAIS, 2010, p. 41-44).

Na verdade, os direitos sociais apresentam, simultaneamente, uma dimensão positiva, que está associada às prestações sociais, e uma dimensão negativa, ou seja, de defesa, de proteção (SARLET, 2007, p. 57). Será mais evidente uma ou outra dimensão se, e na medida em que, esses direitos estiverem mais ou menos concretizados à luz do texto constitucional. Nota-se que, em um Estado Democrático de Direito, e tal como sucede com os direitos de liberdade, ocorreu claramente uma evolução estrutural dos direitos sociais ao longo dos tempos: uma evolução sempre ancorada na carta constitucional e sempre objetivando uma maior e melhor concretização dos direitos, a fim de que estes possam atender mais eficazmente à observância do princípio da dignidade humana (cuja concepção se vai sofisticando) em que está assente o Estado e a ordem jurídica (NOVAIS, op. cit., p. 46). Com efeito, o direito à educação, por exemplo, que se insere claramente no campo dos direitos sociais, pode ser visto primacialmente como um direito negativo, nos casos em que já é assegurado pelo Estado um mínimo social por meio de prestações sociais. O que se exige, nesta hipótese, é que haja uma atitude negativa, de respeito e de proteção, relativamente ao patamar mínimo que já se atingiu, tendo em conta o contexto de universalização da 
educação. ${ }^{10}$ Se, pelo contrário, o Estado social for incipiente, não dispondo de um sistema desenvolvido de prestações sociais, ficará destacada a dimensão positiva do direito à educação, a sua dimensão principal, prestacional (NOVAIS, 2010, p. 44), que obriga o Estado a garantir, por meio de prestações, o acesso ao bem jurídico em causa.

Todavia, se os direitos sociais não são apenas direitos positivos, também é falso associar os direitos de liberdade exclusivamente aos direitos negativos. Relativamente aos direitos de liberdade, e não obstante o seu principal traço distintivo ser o de exigir um dever de abstenção do Estado, há também prestações estatais que são imprescindíveis para garantir a sua verdadeira efetividade, algo que se tornará claro na seção seguinte na abordagem do argumento da "reserva do financeiramente possível".

\subsection{O ARGUMENTO DA RESERVA DO FINANCEIRAMENTE POSSÍVEL COMO CRITÉRIO DISTINTIVO DOS DIREITOS SOCIAIS}

Ora, um argumento muito regularmente usado para justificar uma necessidade de muito maior contenção do juiz perante as omissões do legislador referentes aos direitos sociais estriba-se na ideia de que estes direitos, dada a sua natureza eminentemente prestacional, encontram-se sujeitos às inevitáveis limitações financeiras do Estado em um contexto de relativa escassez de recursos.

Acontece que, como acaba de ser visto, em grande medida, todos os direitos têm uma vertente "positiva" e "negativa" e envolvem, por isso, sempre, para a sua mais genuína efetivação, um dispêndio considerável de recursos. Todos os direitos custam, e caro (HOLMES; SUNSTEIN, 1999). O que normalmente oculta esses custos é, muito provavelmente, uma espécie de "naturalização" e legitimação social das instituições (e respectivos orçamentos) que servem para garanti-los.

\footnotetext{
${ }^{10}$ Nesse mesmo sentido, mas relativamente a outro direito social, o Tribunal Constitucional Português no acórdão 39/84 considerou inconstitucional, por violação do dever negativo de abstenção de destruição do patamar de realização atingido do direito à saúde, um decreto-lei que revogava outro anterior que, por sua vez, havia criado (em lei apenas) o Serviço Nacional de Saúde português, uma instituição constitucionalmente prevista no art. $64^{\circ}$ e possivelmente a mais importante e popular "conquista social" e meio de realização do direito à saúde no país: "a partir do momento em que o Estado cumpre (total ou parcialmente) as tarefas constitucionalmente impostas para realizar um direito social, o respeito constitucional deste deixa de consistir (ou deixa de consistir apenas) numa obrigação positiva, para se transformar ou passar também a ser uma obrigação negativa. O Estado, que estava obrigado a actuar para dar satisfação ao direito social, passa a estar obrigado a abster-se de atentar contra a realização dada ao direito social".
} 
Esta naturalização gera uma dualidade quase imperceptível de critérios que permeia o discurso jurídico dominante. Dois exemplos aqui poderão servir para ilustrar bem este ponto. Quando uma pessoa tem um direito fundamental de liberdade violado pelo Estado e o juiz fixa uma compensação ou uma indenização para que o status quo ante seja restabelecido, i.e., para que seja observado verdadeiramente o regime da indisponibilidade do direito fundamental, o fato de a indenização a ser fixada vir manifestamente a prejudicar o orçamento público nunca é entendido como um critério a ser levado em conta. Na verdade, esse custo foi de tal maneira naturalizado, legitimado, que sua existência quase foi esquecida: tornou-se invisível. E, no entanto, a verdade é que a garantia de efetividade de qualquer direito fundamental implica sempre custos diretos da parte do Estado. Agora, um segundo exemplo a se pensar: os direitos políticos, cuja jusfundamentalidade não suscita dúvidas a ninguém. A garantia da realização de eleições livres, de acordo com um procedimento transparente, só é possível com a alocação de vultosas somas advindas do Estado. É claro que, em um país "habituado" a ter eleições livres, espera-se que os cidadãos não sejam privados de exercer o seu direito a eleger e a ser eleito, e os custos que lhes estão associados tornaram-se "invisíveis" porque foram legitimados e naturalizados. Contudo, em países recentemente democratizados e em que ainda se faz um grande esforço para que essas garantias de liberdade e transparência sejam efetivas, notam-se claramente as dificuldades com o dispêndio financeiro, até porque a viabilidade do direito a eleições livres pode comprometer a realização de outros direitos igualmente valiosos (NOVAIS, 2010, p. 95).

Com efeito, também no caso do direito fundamental de propriedade, o que assegura o regular cumprimento das normas a ele relativas, e dessa forma solidifica ainda a convicção da validade e da importância das mesmas junto da população, é o desenvolvimento e a manutenção de um enorme aparelho burocrático-repressivo cujos custos são muito significativos. De fato, a coercibilidade estatal que protege o direito de propriedade não se exprime por intermédio da mera abstenção do Estado: este direito requer, para a sua efetividade, a existência de um corpo policial, pronto para investigar e reprimir crimes que atentem contra este ou outros bens jurídicos. Entretanto, não é só isso: o direito de propriedade pressupõe a existência de um forte aparelho de justiça (a sua estrutura, os seus funcionários e os agentes indispensáveis para o seu funcionamento) e de um aparato administrativo que lhe dê suporte (registros prediais, cartórios notariais etc.). Toda esta dinâmica do sistema jurídico, não convém esquecer, pressupõe também a existência de 
contínua formação profissional e reprodução de conhecimentos a serem garantidos por intermédio de faculdades de direito e outras instituições públicas ou privadas (adequadamente supervisionadas pelo Estado), sendo que tudo isso implica dispêndio de recursos. ${ }^{11}$

O mesmo se pode dizer do direito à vida: este, além de pressupor o dever, aplicável ao Estado e aos particulares, de não privar alguém da sua vida (NOVAIS, 2010, p. 52), ligase também - indissociavelmente - à ideia de que devem ser garantidas algumas prestações estatais indispensáveis para o desenvolvimento de um "clima” favorável a uma não violação desse direito e ao cumprimento do correspondente dever. É necessário, com efeito, que o Estado garanta proteção policial para quem se encontre em situação de ameaça ou na iminência de sofrer agressão à sua integridade física. Não poderá estar dissociado do direito à vida, ainda, a concretização de alguns direitos sociais, a exemplo do direito aos cuidados de saúde: somente com acesso a cuidados médicos e a medicamentos, de forma universal, será possível que o indivíduo não padeça de forma precoce em razão de enfermidades que podem ser tratadas ou até evitadas.

Observa-se que as dimensões negativas do direito de propriedade, assim como do direito à vida, para usar apenas os dois últimos exemplos, não são suficientes para desenvolver efeitos práticos e, portanto, para fazer desses direitos o bem realmente social e jurídico valioso que todos reconhecem e desejam (NOVAIS, op. cit., p. 94). O moderno constitucionalismo dos direitos fundamentais pressupõe, necessariamente, um complexo sistema de garantias e instituições que garanta efetivamente o respeito, a proteção e a realização de todos os direitos fundamentais, os de liberdade e os sociais.

E é justamente por ser necessário que tal sistema exista e funcione devidamente, que se pode afirmar que a todos os direitos está associado um encargo financeiro do Estado. Assim se prova quão equivocada é a ideia de que a efetividade dos direitos sociais, e somente destes, estaria dependente da existência de recursos financeiros para atender, nos termos do princípio da igualdade, todos aqueles que se insiram nos critérios estipulados para receber auxílio ou prestação estatal.

\footnotetext{
${ }^{11}$ Pelo que conclui Jorge Reis Novais: "qualquer direito negativo só é efectivamente protegido se tiver um remédio, se tiver um sistema administrativo, instituições e um sistema judicial que o garantam, e estes requisitos, designadamente o sistema judicial, significam encargos financeiros avultados; logo, os direitos negativos também custam, os direitos de liberdade são também, tal como os direitos sociais, bens públicos pagos pelos contribuintes" (NOVAIS, 2010, p. 96).
} 
Não se contesta aqui o argumento de que a concretização dos direitos sociais exige um empenho financeiro do Estado e que este não dispõe de recursos para concretizar de forma universalmente generosa todo o elenco de direitos constitucionalmente reconhecidos. Esta é uma realidade incontestável e um argumento, por isso, sólido e razoável que deve acabar por intervir sempre na ponderação do que é razoável e exigível em matéria de direitos sociais constitucionalmente consagrados. O que se contesta, na verdade, é que a objeção da reserva do financeiramente possível seja dirigida somente aos direitos sociais fundamentais, quando a inteira observância dos pressupostos ínsitos aos direitos de liberdade também reclama da administração e do legislador uma conduta ativa, positiva, e, nesse sentido, os direitos de liberdade não se diferenciam dos direitos sociais. Ambos exigem prestações estaduais e, por isso, reserva orçamental e gasto público. Ambos estão sujeitos à "ditadura do financeiramente possível", e, portanto, ambos devem estar limitados por uma certa noção de razoabilidade, proporcionalidade e oportunidade financeira e política.

Se todos os direitos fundamentais têm custos, "levá-los a sério" significa reconhecer que se aceitam eles como o "preço" necessário. Os direitos devem ser realizados, efetivos, garantidos, não belas declarações de intenções que não se materializam em direitos aplicáveis no aqui e no agora e assegurados pela força pública. ${ }^{12}$ E é dentro dos limites das "pré-opções" feitas pelo legislador constituinte originário, ao elevar ao status de fundamental um determinado conjunto de direitos, que se deve admitir a liberdade de conformação do legislador ordinário. Nesse sentido, não cabe ao legislador ordinário, discricionariamente, fazer dos direitos sociais prerrogativas "para não levar a sério". Um direito só tem valor se, e na medida em que, tenha condições de ser exercido efetivamente pelos cidadãos. Foi por isso e para isso que foram consagrados nas constituições. A entender-se os direitos sociais e econômicos de outra forma qualquer, eles não passariam de "poesia constitucional", como Robert Alexy qualifica os direitos fundamentais originalmente consagrados na constituição

\footnotetext{
12 Talvez por, à época, ser ainda tudo muito novo e inseguro, quando o autor liberal Sieyès, no contexto da revolução francesa, redigia uma proposta de declaração dos direitos do homem e do cidadão (essencialmente preocupada com os direitos civis e políticos e também, mais em particular, com o direito de propriedade), sublinhava com veemência a necessidade de assegurar a efetividade (ou, se quisermos, a vertente positiva) desses direitos através dos recursos suficientes - i.e. meios repressivos adequados: "Vainement déclarerait-on que la liberté est le droit inaliénable de tout citoyen; vainement la loi prononcerait-elle des peines contre les infracteurs, s'il n'existait, pour maintenir le droit et pour faire exécuter la loi, une force capable de garantir l'un et l'autre. La garantie de la liberté ne sera bonne que quand elle sera suffisante, et elle ne sera suffisante que quand les coupes qu'on peut lui porter, seront impuissantes contre la force destinée à la defendre. Nul droit n'est completement assuré, s'il n'est protégé par une force relativement irrésistible" (FURET; HALÉVY, 1989, p. 1010).
} 
de Weimar (ALEXY, 2003, p. 33), distinguindo-os dos direitos fundamentais na atual Lei Fundamental alemã. ${ }^{13}$

Na prática, invocar a reserva do possível para sustentar que, na realidade, os direitos sociais só passam juridicamente a existir enquanto tais, isto é, enquanto direitos subjetivos justiciáveis, quando e na medida em que o legislador ordinário os cria, torna sem sentido a sua própria consagração constitucional. Para quê consagrar constitucionalmente algo que simplesmente está na livre disposição do legislador? ${ }^{14}$ A função lídima da Constituição é a de proteger direitos, que se creem "fundamentais" (na concepção ética do legislador constituinte), das flutuações da vontade das maiorias temporárias e respectivos representantes.

A não se entenderem assim, seriamente, os direitos fundamentais sociais, equivaleria a reduzir o efeito prático da sua inclusão no texto constitucional à consagração de uma cláusula geral, de formulação vaga, segundo a qual "o legislador buscará realizar direitos sociais fundamentais conforme estime possível". Como explica Gomes Canotilho (2003, p. 481), "Uma tal construção e concepção da garantia jurídico-constitucional dos direitos sociais equivale praticamente a um 'grau zero de garantia'. (...) Um direito social sob 'reserva dos cofres cheios' equivale, na prática, a nenhuma vinculação jurídica".

\footnotetext{
13 "El artículo 1.3 LF dispone que aquelos derechos fundamentales vinculan como Derecho directamente vigente al Legislativo, al Ejecutivo y al Judicial. Esto significa una ruptura com la tradición constitucionalista del Imperio y de la República de Weimar. En la República de Weimar abundaron los derechos fundamentales vigentes tan sólo como declaraciones programáticas que no gozaban de tutela judicial. Com ánimo polémico si se quiere, cabría decir que se trataba de poesia constitucional (Verfassungslyric). En la república Federal, por el contrario, la observância de todos los derechos fundamentales se halla plenamente controlada por los tribunales, comenzando por los inferiores, así en un tribunal administrativo, y terminando por el Tribunal Constitucional Federal de Karlsruhe." (idem, ibid) Adverte ainda Alexy, na mesma página: "Quien pretenda escribir en la Constitución ideales políticos no justiciables, debe ser consciente de lo que se juega. Com una sola disposición en la Constitución no controlable judicialmente se abre el caminho para la perdida de su obligatoriedad."

${ }^{14}$ Referindo-se aos direitos sociais a que os Estados se vinculam por meio de tratados e pactos internacionais referentes a esses mesmos direitos, mas estendendo essa mesma lógica, por maioria de razão, aos direitos sociais consignados nas constituições, a juíza do Tribunal Superior de Justiça de Buenos Aires (e professora de filosofia do direito na Universidade de Buenos Aires) Alicia Ruiz, considera que esta vinculação cria obrigações sobre os Estados face aos seus cidadãos e que "[t]ales obligaciones estatales presuponen que los derechos que se reconocen son exigibles y que no dependen de la discrecionalidad de la administración o del legislador. Si así fuera las políticas públicas relativas a los derechos sociales dependerían de los 'humores' de la autoridad de turno, no estarían limitadas por la Constitución y por el régimen internacional (...)", acrescentando ainda, fazendo suas as palavras do então secretário judicial da Corte Suprema de la Justicia de la Nación Argentina, Rolando Gialdino: “(...) 'la existencia de un contenido básico pareciera la consecuencia lógica del uso de la terminología de los derechos. No habría justificación para elevar una 'reclamación' a la condición de un derecho...si su contenido normativo pudiera ser tan indeterminado que permitiera la possibilidad de los que ostentan los derechos no posean ningún derecho particular a nada." (RUIZ, 2008, p. 45).
} 
Os governos que pretendem restringir direitos socioeconômicos sempre argumentam e o farão, com razão ou sem ela, como fez notar um antigo juiz do Tribunal Constitucional búlgaro, no sentido de que a situação financeira é muito difícil, justificando assim as medidas propostas. Caso se admitisse que há folga financeira, seria muito mais difícil justificar qualquer medida antissocial. Foi essa consideração, aliás, que levou o Tribunal Constitucional búlgaro, em dada ocasião, a rejeitar como inconstitucional uma medida governamental que pretendia restringir o acesso às pensões de aposentadoria aos indivíduos que não tivessem qualquer outra fonte de rendimento. Deixar que o Estado pudesse livremente determinar o conteúdo do direito à pensão de aposentadoria significaria, segundo os juízes de então, dar uma margem de conformação excessivamente alargada ao governo (SADURSKI, 2005, p. 183-184).

\subsection{O ARGUMENTO DA INCOMPETÊNCIA TÉCNICA DOS JUÍZES PARA JULGAR DEMANDAS FUNDADAS EM DIREITO SOCIAL}

Um outro argumento, talvez não tão usual, usado para fundamentar a necessidade de especial cautela dos juízes e reconhecer uma maior margem de conformação ou discricionariedade ao legislador quando a matéria em questão versar sobre direitos sociais, passa pela invocação da complexidade técnica associada nomeadamente aos efeitos orçamentais e econômicos que lhes seriam próprios. Assim, o fato de que as consequências previsíveis e precisas da implementação de determinadas políticas e medidas - dirigidas à realização desses direitos, sobretudo na sua vertente prestacional - estejam fora das competências e capacidade dos juízes tornaria irrazoável e ilegítimo exigir, ou simplesmente permitir, que este órgão, essencialmente de controle, imiscuísse-se e desautorizasse o legislador e os governos nas suas opções tecnicamente fundamentadas, cujas razões ou justificações lhes escapariam.

Novamente, o argumento tem validade muito relativa. Não é apenas em matéria de direitos sociais que os juízes terão que decidir sobre matérias que pressupõem conhecimentos técnicos em áreas que efetivamente não dominam, nem têm condições para dominar, por inteiro. Pense-se, por exemplo, no caso hipotético de políticas antiterroristas serem postas em prática por um governo e, posteriormente, de essas mesmas políticas serem desafiadas constitucionalmente pelo tribunal, com fundamento na violação do princípio da proibição do 


\section{RFD}

excesso (ou de algum dos seus subprincípios, como o da adequação, necessidade ou proporcionalidade). Para bem julgar esta questão, ou seja, para saber se as políticas antiterroristas instituídas são compatíveis com o princípio da proibição do excesso, seria sempre necessário, ou pelo menos não despiciendo, ter conhecimento sobre o real grau de ameaça terrorista que o país enfrenta atualmente e sobre se ela aumentaria de forma relevante na ausência das políticas propostas. Um juiz ou um tribunal nunca poderá estar na posse da informação completa para decidir corretamente e sem margem para dúvidas nomeadamente não terá acesso aos juízos técnicos dos serviços secretos de informação e outros especialistas - quando se coloquem, em oposição, por um lado, os imperativos da segurança alegados pelo Estado e, por outro, os direitos à mobilidade, à liberdade de expressão, ou à inviolabilidade de domicílio e correspondência. Em qualquer apreciação que um tribunal faça sobre estes conflitos entre direitos fundamentais ou entre direitos e princípios basilares constitucionais, o conhecimento de questões técnicas nunca é irrelevante, e, regra geral, o tribunal não estará "armado" da mesma informação e capacidade nesta matéria do que outras instâncias do Estado (maxime, o governo). No entanto, o juiz, investido da jurisdição constitucional terá que decidir, com base nos elementos que dispuser, se, e até que ponto, a política adotada pelo governo é mesmo razoável e constitucionalmente admissível, ainda que isso implique entrar no que, em princípio, seriam áreas fora da sua competência técnica. Além disso, como se viu, muitos direitos que não os sociais e prestacionais propriamente ditos têm consequências orçamentais e econômicas cuja real extensão só poderia ser aferida de forma adequada se os juízes estivessem munidos de conhecimentos técnicos complexos. Novamente, o argumento revela-se frágil, na medida em que é aplicável não apenas a um tipo específico de direitos, mas a todos. ${ }^{15}$

\subsection{O ARGUMENTO DA FALTA DE LEGITIMIDADE DEMOCRÁTICA DO PODER} JUDICIAL PARA SER UM LEGISLADOR SUBSTITUTO - OU O ARGUMENTO DO "GOVERNO DOS JUÍZES"

\footnotetext{
15 Já se tem admitido em ordenamentos estrangeiros a participação de assistentes técnicos no processo judicial. No Brasil, os juízes e tribunais (assim como o STF em controle concreto e abstrato de constitucionalidade) podem requerer o auxílio técnico de terceiros especialistas dotados dos conhecimentos especializados necessários para esclarecer praticamente qualquer questão que se coloque. Trata-se da figura do amicus curiae. Isto, por si só, já retira qualquer carga dramática ou trágica que se pretendesse atribuir à ideia de ter juízes ignorantes de questões técnicas imiscuindo-se em assuntos para os quais não estão preparados para responder.
} 
De certo modo, pode-se considerar que a consciência da jusfundamentalidade dos direitos fundamentais tem impulsionado a prática e a doutrina constitucional em direção a uma perspectiva mais interventiva ou neoconstitucional. A jurisdição constitucional, por vezes, diante da inércia dos órgãos competentes, ou contra medidas inconstitucionais por eles adotadas, acaba por "criar" direitos, de modo a reduzir as consequências perversas das omissões inconstitucionais ou, simplesmente, de forma a opor-se a um modelo político adotado que afronta as normas constitucionais.

Este tipo de defesa ativa da Constituição, levada a cabo por juízes, diante das falhas da administração pública ou do parlamento, é mais prolífero, sobretudo no caso de textos constitucionais mais sintéticos ou menos densos, como é o caso das constituições alemã e norte-americana, em que não se vislumbra, especialmente no âmbito dos direitos sociais, uma ordem clara e inequívoca do legislador constituinte direcionada aos órgãos de soberania. Aqui, os juízes assumem um papel fundamental na realização de direitos fundamentais, nomeadamente no campo dos direitos sociais, recorrendo mais diretamente aos princípios constitucionais.

Isto não significa, contudo, que o uso da interpretação principiológica no âmbito dos direitos sociais seja exclusivo de tais sistemas. O Tribunal Constitucional Português, por exemplo, embora pese a extensa listagem de direitos sociais na Constituição, faz uso, quando é o caso, de princípios explícitos, tais como o da dignidade humana e da igualdade, e implícitos, como o da proibição do retrocesso social e o da proteção da confiança (NOVAIS, 2004), para dotá-los de efetividade.

Perante esta tendência de abandono da tradicional postura de autocontenção do judiciário (particularmente dos tribunais constitucionais), na sua busca por dotar de maior efetividade os direitos sociais com baixo grau de densificação constitucional, muitos juristas levantam dúvidas quanto à legitimidade político-constitucional dos juízes e dos tribunais de cúpula, à luz da Constituição, para "criarem” direitos subjetivos sociais. Ao conceder tão ampla margem interpretativa aos juízes e uma força expansiva, invasiva mesmo, aos direitos e princípios constitucionais, não se estaria correndo o risco assim de atentar contra a separação de poderes e o princípio democrático?

Afirma-se que os juízes não são eleitos, que o seu poder não tem origem no exercício da soberania popular e que, por isso mesmo, não deveriam poder "legislar" em substituição daqueles que foram legitimados para o fazer. Quanto mais implícitos os princípios e quanto 


\section{RFD}

menos densificados a nível constitucional os direitos, mais potencialmente "perigosas" se tornariam as leituras criativas dos juízes que contrariem o direito legislado, porque mais razoável se torna a dúvida e a divergência em torno do significado real daquilo que a Constituição efetivamente impõe. De fato, não seria possível retirar de uma disposição constitucional abstrata, principiológica, de conteúdo aberto, um sentido único, nem seria possível que o intérprete realizasse uma atividade de mera revelação do direito sem realizar qualquer papel criativo (BARROSO; BARCELLOS, 2003, p. 102).

Ademais, não é possível olvidar que a legitimidade democrática do legislador, enquanto representante de uma maioria de cidadãos politicamente iguais, deve-lhe valer de alguma coisa, sob pena de o princípio "um homem, um voto" ser completamente desvalorizado: a sua produção normativa, enquanto vontade da maioria, deveria gozar de uma presunção de constitucionalidade, ainda que ilidível. Os tribunais, incluindo os constitucionais e supremos, por contraste, não foram devidamente legitimados para se substituírem ao legislador e aos governos, pelo que não thes poderia ser reconhecida a incumbência e o direito de definir a política ordinária, sob pena de usurpação antidemocrática de funções e violação da separação de poderes.

Este é um argumento relevante e que exige a devida consideração, mas nem por isso inultrapassável. Não há dúvidas de que o princípio democrático é do tipo estruturador das nossas sociedades, que convida todos os cidadãos a participarem do jogo político, em termos de igualdade, a fim de escolher os seus representantes. Este princípio encerra certa noção de justiça política e legitima a regra da decisão pela vontade da maioria (ou dos seus representantes). Poder-se-ia argumentar, até, de forma mais contestável, que, por convocar todos a participar das decisões, o princípio democrático tenderia a gerar decisões mais justas. Contudo, este princípio não é o único, nem, provavelmente, o mais importante valor que as sociedades contemporâneas e as suas constituições procuram realizar: existem outros valores e princípios constitucionais igualmente valiosos, que servem justamente para limitar, controlar, vigiar o poder exercido pelos governantes (NOVAIS, 2014, p. 25 e ss.) e garantir, assim, maior justiça na sociedade. O princípio democrático, e a regra da decisão pela maioria, portanto, ainda que tenham um lugar de destaque nas constituições modernas, não podem ser considerados absolutos, nem a "presunção de constitucionalidade" das normas do legislador democrático inilidível. 
A justiça constitucional e a sua função fiscalizadora, na busca pela defesa da constituição material, deve funcionar como um contrapoder ao político e assume, assim, um papel central na ideia de Estado de Direito. Em uma concepção forte de Estado de Direito, que seja simultaneamente formal e material, esta expressão designa todos os ordenamentos jurídicos em que os poderes públicos estão "sujetos a la ley (y, por tanto, limitados o vinculados por ella), no sólo en lo relativo a las formas, sino también en los contenidos" (FERRAJOLI, 2003, p. 13).

O poder político democrático, no "Estado de Direito democrático", tem certa liberdade para interpretar e concretizar os escopos constitucionais, mas não está totalmente livre: ele está vinculado a um conjunto de "tarefas constitucionais objetivas" que o obrigam a realizar os pressupostos indispensáveis para a concretização dos direitos fundamentais, dentre eles os de natureza social (QUEIROZ, 2006, p. 16). Na realidade, os princípios estruturantes e os direitos fundamentais foram constitucionalizados precisamente porque são considerados extremamente preciosos para que possam estar na livre disposição das maiorias temporárias e das suas flutuações arbitrárias. Afinal, como lembra Luigi Ferrajoli, é errado pensar que uma norma e um direito só são legítimos ou têm valor na exata medida em que têm a sua origem na vontade da maioria: os direitos fundamentais constitucionalmente consagrados funcionam como a "lei do mais fraco" contra o que de outra forma seria a "lei do mais forte" (FERRAJOLI, 2007, p. 82 e ss).

A aprovação da maioria dá alguma legitimidade ou um tipo de legitimidade a uma política, medida ou norma, mas a legitimidade de uma norma pode residir - e ser inclusive mais "forte" do que a legitimidade democrática - no bem jurídico que ela se destina a proteger para a fruição de todos os cidadãos, independentemente da opinião da maioria, e mesmo contra esta. Ora, citando Ferrajoli: "siempre que se quiere tutelar un derecho como fundamental se lo sustrae a la política, es decir, a los poderes de la mayoria, y por outro lado al mercado, como derecho inviolable, indisponible e inalienable" (FERRAJOLI, op. cit., p. $85)$.

As constituições espelham, como se disse, múltiplos objetivos; consagram diversos e relativamente contraditórios princípios de justiça que pretendem realizar e operam uma difícil, mas necessária, acomodação entre estes vários princípios e direitos. O princípio democrático, e particularmente o seu corolário do método de decisão por voto maioritário, em constituições como a portuguesa e a brasileira, está limitado pelos direitos fundamentais 
e outros princípios e valores. Isto é válido tanto para direitos de natureza mais prestacional como para os de natureza mais notoriamente "negativa". Seria possível alegar, contudo, que, com a interferência forte da jurisdição constitucional no domínio dos direitos sociais e econômicos e, portanto, também das opções orçamentais e econômicas do legislador, o espaço de conformação deste último ficaria radicalmente confinado e o papel dos juízes seria indevidamente alargado, a ponto de se ofender ou tirar significado prático ao princípio democrático. O argumento seria, portanto, que, novamente, há algo de distinto nos direitos sociais.

Não se vê, no entanto, porque deva ser assim. As disposições constitucionais relativas a típicos direitos de liberdade implicam, também elas, uma limitação significativa do poder de conformação do legislador, sem que ninguém se lembre de alegar, todavia, que isto constitui uma violação do princípio democrático. Não são, portanto, apenas os direitos sociais; não é apenas a sua retirada da total disponibilidade de conformação do legislador e governos que constrange estes últimos. Toda a consagração e proteção de direitos fundamentais pela justiça constitucional, independente de sua natureza, implica retirar significativa liberdade de conformação ao legislador democrático. E, ainda para mais, como se viu, todos os direitos têm vertentes negativas e positivas e implicam custos vultuosos. ${ }^{16} \mathrm{O}$ legislador constituinte, ao consagrar qualquer direito, buscou colocá-lo em uma dada lista de prioridades que o legislador ordinário não deveria ter liberdade para ignorar. Naturalmente, o legislador ordinário tem direito a ter as suas próprias prioridades, mas, ainda assim, deverá sempre legislar e agir (ou deixar de agir) dentro de um quadro geral que lhe é imposto pela Constituição.

Poder-se-ia ainda argumentar, contudo, que os direitos políticos e civis relacionam-se mais estreitamente com o próprio princípio democrático, que são condição necessária para a possibilidade da própria democracia e que, portanto, limitar nesta matéria o legislador democraticamente eleito seria garantir a preservação no tempo das pré-condições da democracia. Isto é certo, sem dúvida, mas, pelo menos no caso das concepções de democracia que subjazem aos textos constitucionais modernos - e que rejeitam o formalismo redutor dos

\footnotetext{
${ }^{16}$ Pensa-se, por exemplo, na proibição da pena de morte na Constituição Portuguesa (art. 24, n 2 ). Esta, fundada no direito à vida e no princípio da dignidade da pessoa humana, não apenas limita um eventual legislador ordinário que, fundado na sua particular ideologia e com respaldo popular, quisesse introduzir a pena de morte, mas também impõe custos que não se podem invocar contra esta proibição e que deverão ser suportados mesmo por um legislador que, por exemplo, argumentasse que manter vivos, alimentados e vigiados criminosos condenados a longas penas se revela extremamente caro para o Estado.
} 
regimes liberais burgueses do passado -, a verdade é que os direitos civis e políticos são condição necessária, mas não suficiente, para a salvaguarda da democracia. Os direitos fundamentais civis, políticos, sociais e econômicos são vistos todos como condições da democracia, reforçando-se todas mutuamente e permitindo o aprofundamento da democracia em um sentido mais genuíno. ${ }^{17}$ É precisamente nestes termos que Gomes Canotilho lê o princípio da democracia social, econômica e política como critério interpretativo (embora, diga-se em abono da verdade, não como "fundamento imediato e autônomo de pretensões jurídicas") da Constituição portuguesa, particularmente relevante em matéria de direitos fundamentais (CANOTILHO, 2003, p. 341 e ss).

Naturalmente, o exato ponto a partir do qual se deve considerar o constrangimento do legislador constituinte e do juiz incompatível com o princípio democrático, variará de uma cultura (jurídica e política) para outra. Nos modelos de inspiração mais francesa, na qual, fruto de uma cultura revolucionário-democrática de longa data e tradição, os legisladores constituintes sempre se mostraram relutantes, para não dizer hostis mesmo, à interferência dos juízes na esfera mais "político-constitucional", tendo a lei, pela sua origem nos representantes democraticamente eleitos, uma presunção de legitimidade quase avassaladora, o peso e legitimidade relativa dos órgãos de fiscalização constitucional tende a ser menor. Pelo contrário, em sistemas mais influenciados pela tradição americana da judicial review, entendida como pilar essencial de uma sociedade justa e bem ordenada, a legitimidade de uma postura mais "proativa" do judiciário, e da suprema corte mais em particular, surge como evidente e raramente em conflito com um "bom entendimento" do princípio democrático. Nesse aspecto, Portugal e Brasil podem apresentar inclinações históricas divergentes: o primeiro, com tribunais historicamente autocontidos; o segundo, com tribunais assumindo um papel de protagonista. Contudo, nota-se, não apenas no Brasil,

\footnotetext{
${ }^{17}$ Na verdade, realização mais conseguida de alguns direitos é condição, senão de possibilidade, pelo menos de efetividade e valor prático dos demais. Como refere a Juíza do Tribunal Superior de Justiça de Buenos Aires e professora de Filosofia do Direito na Universidade de Buenos Aires Alicia E. Ruiz, citando a propósito trechos de sentenças desta corte argentina: "los derechos sociales son de igual jerarquía e igual estructura que los demás derechos humanos y todos tienen carácter interdependiente. La interdependência de los derechos es evidente, pues, por ejemplo, resulta difícil de qué manera puede estar protegido el derecho a la salud si no se tiene techo o si se vive en condiciones inhumanas de hacinamento....De igual manera no se ve cómo los niños que forman parte de la familia... podrían ejercer adecuadamente su derecho a la educación si ellos, antes o después de asistir a sus clases tienen que desarrollar su vida en la calle. La interdependencia de los derechos muestra que desprotegido uno de ellos, se pierden los restantes en un processo de creciente vulnerabilidad jurídica que tiende a consolidar la desigualdad social que pasa a convertirse en persistente...qué sentido tiene la protección de la vida privada y familiar y la inviolabilidad del domicilio y la correspondencia, respecto de quienes se vem compelidos a vivir en los umbrales de los edificios, en las plazas públicas." (RUIZ, 2008, p. 44).
} 
mas também em Portugal - e no globo inteiro, graças ao ímpeto neoconstitucional - uma crescente legitimidade relativa dos tribunais com jurisdição constitucional e do seu papel mais interventivo na defesa do conteúdo (e não apenas das formas) das disposições constitucionais.

O argumento de que é ilegítima a interferência do judiciário na política ou na atividade dos poderes democraticamente eleitos é normalmente utilizado como estratégia para criticar certos posicionamentos judiciais que, em prol da efetividade da Constituição, colocam embaraços às políticas públicas adotadas, sobretudo em períodos de crise econômica. Todavia, convém lembrar que, se o legislador sentir que os constrangimentos financeiros criados pelas novas realidades econômicas, ou que simplesmente a sua sensibilidade política militam fortemente contra estas pré-opções do legislador constituinte, pode sempre alterar, por meio de um processo de revisão constitucional, as pré-opções feitas pelo texto constitucional, dentro de certos limites. Assim, devidamente legitimado, pode o legislador de hoje proceder a uma flexibilização radical dos direitos fundamentais. Nesse caso, claro, precisará de uma maioria qualificada no parlamento e de um respaldo popular que pode ser difícil de obter, mas isto faz sentido, atendendo precisamente ao fato de que estará alterando aspetos essenciais da estrutura básica da sociedade - algo que as constituições buscam proteger de mudanças arbitrárias ou irrefletidas. Daí a necessidade de assegurar uma legitimidade "mais do que democrática", que vá para além da mera concordância da maioria para poder tocar de forma substancial em matérias tão críticas. No caso específico do Brasil, contudo, a solução que acabou de se esboçar será impossível, uma vez que é vedado ao legislador constituinte derivado pretender abolir os direitos e garantias individuais, conforme o disposto no art. 60, inciso IV, CF/88.

Em todo o caso, cada cultura jurídico-política definirá qual a margem de liberdade interpretativa que julga poder ser toleravelmente reservada ao juiz e ao legislador respectivamente, em função das experiências históricas e políticas peculiares a cada país. ${ }^{18}$

\footnotetext{
${ }^{18}$ Se nos países de common law se admite facilmente que o legislador possa manter-se silencioso e parcimonioso, de modo que os juízes, recorrendo a um direito comum formado e decantado ao longo de décadas e séculos de precedentes jurisprudenciais, tornam-se os verdadeiros determinadores do Direito, na Europa continental não se aceita que se deixe "a un juez libre los problemas últimos del ajuste social". Isto se deve, em parte, como se referiu, à ideologia democrática herdeira da revolução francesa (GARCIA DE ENTERRÍA; MENÉNDEZ MENÉNDEZ, 1997, p. 31 e ss.). Neste caso, o direito tem necessariamente uma forte base legislativa, pois é a função (e dever) dos representantes em uma sociedade democrática exprimir a vontade popular, de modo que, "[p]or mucho que se resalte la crisis de la Ley en las sociedades actuales, tal crisis no alcanza en modo alguno a destronar la Ley (en el ámbito de la Constituición, naturalmente, que no es sino la lex superior) de ese lugar central e insustituible" (ibid, p. 53-54).
} 


\section{CONCLUSÕES}

Ao longo das breves considerações aqui tecidas, buscou-se demonstrar a frágil base em que estão assentes os diversos argumentos que tentam cindir os direitos fundamentais em dois grupos: um mais importante, mais jusfundamental ou mais essencial do que o outro. Em contextos de crise econômica, o argumento da escassez de recursos é poderosamente combinado com a noção de que é necessário definir prioridades e sustenta-se que é imperativo preterir os direitos sociais que apresentariam características específicas e únicas que tornariam o seu cumprimento secundário e mais difícil.

Neste ambiente ideológico e econômico, tende a surgir um constitucionalismo de exceção que vincula as possibilidades de realização dos direitos sociais fundamentais à disponibilidade orçamental. Pior ainda, o único juiz dessa disponibilidade - ou pretensa falta dela -, para tais correntes, é o próprio poder político que assim se vê livre de qualquer controle constitucional. Não se negou aqui que os representantes democraticamente legitimados devem gozar de certa discricionariedade na gestão das finanças do Estado, de modo a cumprir a sua própria agenda e programas. Tampouco se nega a escassez relativa de recursos como condicionante de toda a política. Contudo, uma teoria forte do constitucionalismo (o neoconstitucionalismo) não é compatível com uma constituição a duas velocidades, com normas e direitos fundamentais de diferente valor, uns para levar a sério, com direito à proteção do controle judicial da constitucionalidade, e outros para considerar como um conjunto de pias recomendações, de conselhos sem força vinculativa, vãs palavras sem qualquer utilidade normativa.

As características pretensamente únicas dos direitos sociais e as condicionantes que delas resultariam são, afinal, as de todos os direitos fundamentais. Todos os direitos contemplam uma dimensão "positiva" e todos envolvem vultosos custos orçamentais para a sua realização prática. Todos podem ser potencialmente indeterminados. Mais importante ainda, a avaliação pelo poder judicial das opções do legislador democrático no sentido de restringir qualquer direito fundamental (social ou não) levanta sempre idênticos problemas quanto à competência técnica dos juízes e quanto à legitimidade político-constitucional desses julgamentos: nomeadamente o receio de se abrir as portas ao "governo dos juízes" e à violação da separação de poderes. Assim, com crise ou sem ela, não há como alegar que os 
direitos fundamentais sociais merecem menor proteção jurisdicional ou que devem ser considerados superiormente sujeitos ao princípio constrangedor da reserva do possível. O texto constitucional e os seus direitos constituem um todo de igual normatividade, e qualquer omissão ou ação do poder político que viole uma só das suas disposições deverá estar sujeita ao seu questionamento por cidadãos e instituições, que podem instar o Poder Judiciário a se pronunciar sobre a matéria e, assim, a dar efetividade prática e supremacia jurídica aos limites impostos pelo modelo de Estado e sociedade que a Constituição imperativamente definiu.

Não se pode olvidar que a Constituição representa um "contrato social” fundamental, um pactum societatis, no qual se acordam as bases necessárias para a convivência pacífica e para o respeito recíproco, a fim de evitar conflitos ou guerras civis. Nesse pacto, há o compromisso de os indivíduos obedecerem e se sujeitarem às decisões do governo legítimo, porque estabelecer regras de convivência sem sujeitar os indivíduos a um poder coletivo gera impotência; mas o poder coletivo deverá respeitar as condições mínimas, as bases do pacto, sob pena de revelar-se tirano (ZAGREBELSKY, 2008, p. 29-30). Os direitos fundamentais, dentre eles os sociais, são parte integrante desse contrato social e descumpri-los ou desprotegê-los, bloqueando a sua justiciabilidade, portanto, é violar esse mesmo contrato social.

\section{REFERÊNCIAS}

ALEXY, Robert. Los derechos fundamentales en el Estado Constitucional Democrático. In: CARBONELL, Miguel. Neoconstitucionalismo(s). Madrid: Trotta, 2003. p. 21-37.

AMARAL, Maria Lúcia. Direito Constitucional II, Sumários Desenvolvidos. Lisboa: Faculdade de Direito da Universidade Nova de Lisboa, s/d.

BARROSO, Luís Roberto; BARCELLOS, Ana Paula de. A nova interpretação constitucional: ponderação, argumentação e papel dos princípios. In: Dos princípios constitucionais: considerações em torno das normas principiológicas da Constituição. São Paulo: Malheiros, 2003. p. 101-135.

BERNAL PULIDO, Carlos. Refutación y defensa del Neoconstitucionalismo. In: CARBONELL, Miguel (Org.). Teoria del neoconstitucionalismo. Ensayos escogidos. Madrid: Trotta, 2007. p. 289-326. 
BOBBIO, Noberto. A Era dos Direitos. Trad. Carlos Nelson Coutinho. Rio de Janeiro: Editora Campus, 1992.

CANOTILHO, J. J. Gomes. Direito Constitucional e Teoria da Constituição. 7. ed. Coimbra: Almedina, 2003.

CENTRO DE ESTUDOS SOCIAIS - CES (Laboratório Associado à Universidade de Coimbra). Anatomia da crise: identificar os problemas para construir as alternativas. $1^{\circ}$ relatório, preliminar, do Observatório sobre Crises e Alternativas. Disponível em: $<$ http://www.ces.uc.pt/ficheiros2/files/Relatorio_Anatomia_Crise_final_.pdf $>$. Acesso em: 04 mai. 2015.

. Barômetro das Crises. Observatório sobre crises e alternativas, $\mathrm{n}^{\circ} 13$, Crise e mercado de trabalho: Menos desemprego sem mais emprego?, publicado em 26/03/2015. Disponível em:

$<$ http://www.ces.uc.pt/observatorios/crisalt/documentos/barometro/13BarometroCrises_Cris e\%20mercadotrabalho.pdf >. Acesso em: 04 mai. 2015.

. Barómetro das Crises. Observatório sobre as crises e alternativas, n 19. Emprego e salários: pontos de interrogação, publicado em 22/11/2018. Disponível em: <https://www.ces.uc.pt/ficheiros2/files/19BarometroCrises_Interrogacao16112018.pdf>. Acesso em: 02 fev. 2019.

. Barómetro das Crises. Observatório sobre as crises e alternativas, $\mathrm{n}^{\circ} 18$, Retoma económica: o lastro chamado precariedade, publicado em 05/01/2018. Disponível em: $<$ https://www.ces.uc.pt/ficheiros2/files/18BarometroCrises_Retoma_precariedade.pdf $>$. Acesso em: 02 fev. 2019.

DWORKIN, Ronald. Taking Rights Seriously. Cambridge: Cambridge University Press, 1997.

FERRAJOLI, Luigi. Pasado y Futuro del Estado de Derecho. In: CARBONELL, Miguel (Org.). Neoconstitucionalismo(s). Madrid: Trotta, 2003. p. 13-29.

Sobre los derechos fundamentales. In: CARBONELL, Miguel (Org.) Teoria del neoconstitucionalismo. Ensayos escogidos. Madrid: Trotta, 2007. p. 71-89. 


\section{RFD}

FURET, François; HALÉVY, Ran. Orateurs de la Révolution Française: Les Constituants. Bruges: Gallimard, 1989. v. 1.

GARCIA DE ENTERRÍA, Eduardo; MENÉNDEZ MENÉNDEZ, Aurelio. El Derecho, la Ley y el Juez. Dos estudios. Madrid: Civitas, 1997.

GUASTINI, Riccardo. La “Constitucionalización” del ordenamiento jurídico: el caso italiano. In: CARBONELL, Miguel (Org.). Neoconstitucionalismo(s). Madrid: Trotta, 2003. p. 39-64.

GRINOVER, Ada Pellegrini. O controle de políticas públicas pelo Poder Judiciário. In: $O$ Processo: Estudos e Pareceres. 2. ed. rev. e ampl. São Paulo: DPJ, 2009. p. 36-57.

HART, Herbert L. A. O conceito de Direito. 5. ed. Trad. A. Ribeiro Mendes. Lisboa: Fundação Calouste Gulbenkian, 2007.

HOLMES, Stephen; SUNSTEIN, Cass. The cost of rights: why liberty depends on taxes. Nova York: W. W. Norton \& Co., 1999.

KLEIN, Naomi. The shock doctrine: the rise of disaster capitalism. Nova York: Metropolitan Books, 2008.

NOVAIS, Jorge Reis. Os princípios constitucionais estruturantes da República Portuguesa. Coimbra: Coimbra Editora, 2004.

. Direitos Sociais. Teoria Jurídica dos Direitos Sociais enquanto Direitos Fundamentais. Coimbra: Wolters Kluwer e Coimbra Editora, 2010. 2014 . Em defesa do Tribunal Constitucional: resposta aos críticos. Coimbra: Almedina,

PIOVESAN, Flávia. Justiciabilidade dos direitos sociais e econômicos: desafios e perspectivas. In: CANOTILHO, J. J. Gomes; CORREIA, Marcus Orione Gonçalves; CORREIA, Érica Paula Barcha (Coords). Direitos Fundamentais Sociais. São Paulo: Saraiva, 2010. p. 53-69. 
PORTUGAL. Tribunal Constitucional. Acórdão n 39/84. Relator: Cons. Vital Moreira. Lisboa, 11 de abril de 1989. Disponível em: <http://www.tribunalconstitucional.pt/tc/acordaos/19840039.html>. Acesso em: 13 out. 2014.

. Acórdão n 509/2002. Relator: Cons. Luís Nunes de Almeida. Lisboa, 19 de dezembro de 2002. Disponível em:

<http://www.tribunalconstitucional.pt/tc/acordaos/20020509.html>. Acesso em: 13 out. 2014.

PRIETO SANCHÍS, Luis. El Constitucionalismo de los Derechos. In: CARBONELL, Miguel (Org.). Teoria del neoconstitucionalismo. Ensayos escogidos. Madrid: Trotta, 2007. p. 213236.

QUEIROZ, Cristina. Direitos Fundamentais Sociais. Funções, Âmbito, Conteúdo, Questões Interpretativas e Problemas de Justiciabilidade. Coimbra: Coimbra Editora, 2006.

RIBEIRO, Gonçalo de Almeida; COUTINHO, Luís Pereira (Org.). O Tribunal Constitucional e a Crise: Ensaios Críticos. Coimbra: Almedina, 2014.

RUIZ, Alicia E. C. La realización de los derechos sociales en un Estado de Derecho. In: OLIVEIRA NETO, Francisco José Rodrigues et al. Constituição e Estado Social: os obstáculos à concretização da Constituição. Coimbra: Coimbra Editora, 2008. p. 41-48.

SADURSKI, Wojciech. Rights before Courts: a study of Constitutional Courts in Postcommunist States of Central and Eastern Europe. Dordrecht: Springer, 2005.

SARLET, Ingo Wolfgang. A eficácia dos direitos fundamentais. 7. ed. rev., atual. e ampl. Porto Alegre: Livraria do Advogado, 2007.

. Segurança social, dignidade da pessoa humana e proibição do retrocesso: revisitando o problema da proteção dos direitos fundamentais sociais. In: CANOTILHO, J. J. Gomes; CORREIA, Marcus Orione Gonçalves; CORREIA, Érica Paula Barcha (Coords). Direitos Fundamentais Sociais. São Paulo: Saraiva, 2010. p. 71-109.

ZAGREBELSKY, Gustavo. El derecho dúctil. 9. ed. Trad. Marina Gascón. Madrid: Trotta, 2009. 

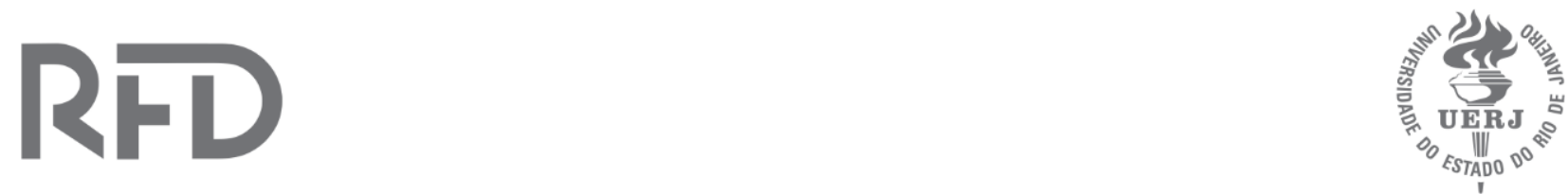

Principios y votos. El Tribunal Constitucional y la política. Trad. Manuel Martínez Neira. Madrid: Trotta, 2008. 